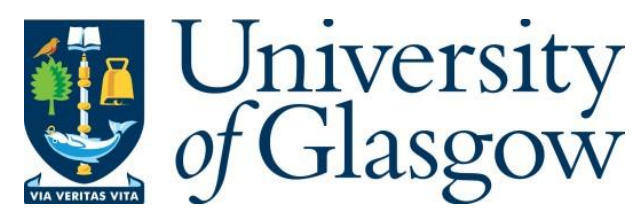

Alves, I. (2020) Enacting education policy reform in Portugal - the process of change and the role of teacher education for inclusion. European Journal of Teacher Education, 43(1), pp. 64-82.

There may be differences between this version and the published version. You are advised to consult the publisher's version if you wish to cite from it.

http://eprints.gla.ac.uk/203426/

Deposited on: 16 March 2020

Enlighten - Research publications by members of the University of Glasgow http://eprints.gla.ac.uk 


\title{
Enacting Education Policy Reform in Portugal - the Process of Change and the Role of Teacher
}

\section{Education for Inclusion}

\begin{abstract}
The international trend to develop inclusive systems, has resulted in pressure on national governments to develop policies that promote quality education for all. In 2017-18 Portugal has adopted progressive educational policies with regards to inclusive education, that attempt to reconcile school values, curriculum and pedagogies. This article critically analyses changes proposed by this wave of educational policy reform and establishes the need for a srong continuous professional development of mainstream teachers to support them to develop as reflexive and inclusive practitioners. The analysis applies two models of change to examine the 'policy ecology' and consider the initiatives used to enact change in Portuguese schools. The policies have prioritised the development of schools in which all students are welcome, able to participate and succeed. While this wave of policy reform has relied both on formal and non-formal forms of teacher education, there is a danger of superficial approaches that may not support teachers in the process of change.
\end{abstract}

\section{Introduction}

The international trend to develop inclusive systems, has resulted in pressure on national governments to develop policies that promote quality education for all. In 2017-18 Portugal adopted progressive educational policies with regards to inclusive education, that attempt to reconcile school values, curriculum and pedagogies. This study will approach policy through a notion of educational policy 'ecology' (Weaver-Hightower, 2008) and critically analyse the changes in policy and the initiatives promoted by the Portuguese Ministry of Education in the process of enacting the wave of policy reform that occurred in Portugal during the academic year of 2017-18. This policy reform aimed to develop a more inclusive education system in which mainstream schools and teachers were to be the main characters in the process of change. The initiatives to enact the policy reform will be analysed through established models about processes of organisational change by Lewin (1947) and Kotter \& Schlesinger (1979). The research aims to address the following research questions: What changes took place in educational policy in Portugal related to inclusion, during 2017-18? What processes were used to 
implement these changes? And what role did teacher continuous professional development play in this process?

While the framework used in this article is applied to the Portuguese context, it is suggested that this structure can be useful to interrogate policy-driven processes of change in educational systems in other countries.

\section{International trends towards inclusive education}

International governance bodies such as the United Nations have placed inclusion, non-discrimination, and equity at the top of their priorities regarding education. For example, the Sustainable Development Goals (SDG) aim to develop quality education, by ensuring equal access to education 'for the vulnerable, including persons with disabilities, indigenous peoples and children in vulnerable situations', and by the creating 'inclusive and effective learning environments for all' (United Nations, 2015, p. 19). Building on the 'legacy of the Salamanca Statement' (Ainscow, Slee and Best, 2019, p. 671), the SDG have put inclusive education at the forefront of the quest to create a more just world. Similarly, the United Nations Convention on the Rights of Persons with Disabilities' (CRPD) has also brought inclusive education to the foreground in the global arena. Article 24 of the CRPD, which focusses on Education, defines education as a right and claims that inclusive education is the way to fulfil this right without discrimination and on the basis of equal opportunity. This document refers to a specific group - persons with disabilities - and establishes the expectation that they 'are not excluded from the general education system on the basis of disability', and 'can access an inclusive, quality and free' education 'on an equal basis with others in the communities in which they live' (United Nations, 2006, p. 17).

Inclusive education requires schools to change to respond to all learners, namely those considered 'vulnerable' and 'persons with disabilities'. Nonetheless, the target population of inclusive education, depending on the contexts, can refer to either pupils with special educational needs (SEN) and disabilities or a broader group of pupils, those who are considered vulnerable or who might experience difficulties at school (Moltó et al., 2010).

The academic literature has been pointing, for several years, to the development of inclusive education systems, aiming to ensure access to quality education for all children based on principles of rights, equity, and participation (Pijl, Meijer and Hegarty, 1997; Dyson, 1999; Thomas and Vaughan, 2004).

International trends point towards inclusion being 'about all pupils, not just a few' (Mittler, 2000, p. 177) 
and to inclusive education requiring whole school policies and practices and restructuring schools to accommodate all pupils.

UNESCO defines inclusion as a 'process that helps to overcome barriers limiting the presence, participation, and achievement of learners' (UNESCO, 2017, p. 7) and inclusive education as the 'process of strengthening the capacity of the education system to reach out to all/span>learners' (UNESCO, 2017, p. 18). The European Agency for Special Needs and Inclusive Education (2017, p. 1) considers inclusive education systems those that 'ensure that all learners of any age are provided with meaningful, highquality educational opportunities in their local community, alongside their friends and peers'. So, inclusive education systems work to identify and remove barriers to access, participation and success of all learners to education.

Key publications such as The Index for Inclusion (Booth and Ainscow, 2002, 2011) have supported schools, teachers and policy-makers in reflecting on how, and whether, they are creating inclusive environments. However, inclusion remains at some levels 'a grand project' pushed internationally as a 'policy priority' (Armstrong, Armstrong and Spandagou, 2011, pp. 37-38).

In Portugal there has been a move towards inclusion since the 1970s (Costa and Rodrigues, 1999; Rodrigues and Nogueira, 2011), and 2017 saw a new 'wave of policy reform' (Hargreaves and Goodson, 2006, p. 13) that aimed to develop a more inclusive education system. Portugal has 12 years of compulsory schooling, organised into four levels: $1^{\text {st }}$ cycle of basic education $( \pm 6-10$ years old $), 2^{\text {nd }}$ cycle of basic education $( \pm 10-12), 3^{\text {rd }}$ cycle of basic education $( \pm 12-15)$, secondary education $( \pm 15-18)$. By and large, all students are expected to attend their catchment area mainstream school, and special schools are an exception, catering for the needs of around $1 \%$ of the student population. This new wave of policy reform had at its core the development of inclusive education and creating a school for all children in compulsory education (primary and post-primary: 6-18 year olds). In the following section, the role of teacher education will be discussed, with regards to the creation of a more inclusive education system.

\section{Teacher continuous professional development for inclusion}

The expectations for Teacher Education (TE) are high: to develop teachers who know about pedagogy and who have the 'skills to construct and manage classroom activities efficiently, to communicate well, use technology, and reflect on their practice to learn from and improve it continually' (Darling- 
Hammond, 2006, p. 300). Rouse (2008), proposes that TE for inclusion must involve three aspects: 'knowing', 'doing' and 'believing'. So, TE for inclusion has an added challenge of requiring teachers to question their assumptions about diversity, to (re)consider the role and functioning of schools, namely by finding ways to work collaboratively with others. Florian (2012) argues that these are challenging tasks to be accomplished through initial teacher education alone, and that continuous professional development (CPD) for diversity must afford teachers opportunities to develop an understanding of social justice and of learning that takes into account differences between learners. TE for inclusion should include 'knowing' about the policy context, teaching and classroom management strategies, understanding how children learn, knowing how to assess learning, how to identify difficulties and how to find help when needed (Rouse, 2008).

However, in-service courses, conferences and policy documents seldom contribute significantly to change as they often do not create "interruptions that help to "make the familiar unfamiliar" in ways that stimulate self-questioning, creativity, and action' (Ainscow, 2005, p. 116).

CPD for inclusion requires 'doing', turning knowledge into action through school- and classroom-based, action-research projects (Rouse, 2008), developing a reflective attitude towards teaching practice to better accommodate the diversity of needs within classrooms (European Agency for Special Needs, 2012) and finding ways of becoming active professionals who work together (Florian, 2012). Hence, CPD must move beyond intellectually superficial (Borko, 2004, p. 3) and 'fragmented in-service training' (DarlingHammond, 2017, p. 303). Teacher education for inclusion requires school-based, competency- and reflection-based approaches to CPD (Creemers, Kyriakides \& Antoniou, 2013) that allow teachers to experiment in a supported way, interact with others and reflect (Borko 2004; Bakkenes, Vermunt, and Wubbels 2010; Meijer 2013; Meirink et al. 2009). Peer observations (Caena, 2011), collaborative approaches (Vangrieken et al. 2015), the analysis of the students' reactions (Flores, 2005) and engaging with student voice (Messiou et al., 2016) are effective ways to 'create interruptions' (Ainscow, 2005, p. 116) and develop more inclusive schools.

TE must also afford opportunities for teachers to develop 'inclusive thinking' and 'beliefs' that 'all children are worth educating; That all children can learn; That they [teachers] have the capacity to make a difference in children's lives; That such work is their responsibility and not only a task for specialists' (2008, p. 14). Beliefs about students' abilities being 'fixed' (Hart et al., 2004) and that 'most phenomena (e.g. intelligence, ability, performance) can be distributed according to the statistical principles of the 
normal curve' (Florian, 2019, p. 695) will have an impact on teacher's behaviour and expectations regarding their students. For example, assumptions about diversity might undermine pedagogical innovations when teachers believe that students are 'disadvantaged and in need of fixing, or, worse, as deficient and, therefore, beyond fixing' (Ainscow, 2005, p. 117). Ensuring that all learners succeed within existing educational systems is a challenge, and research suggests that many teachers may not have the knowledge, skills and attitudes, or feel unprepared to support all learners and create inclusive education (Forlin, Douglas and Hattie, 1996; Forlin, 2001). Teachers report unpreparedness in responding to diversity across Europe (Arnesen et al., 2008; Burns and Shadoian-Gersing, 2010; European Commission, 2015, 2017) including Portugal (Flores and Ferreira, 2016). Developing schools where all learners can participate and learn requires teachers to 'recognize that they do have the power, and indeed the responsibility, to act as agents of change' (Lloyd, 2010, p. 147), 'weavers of difference, in transforming classrooms into inclusive cultures' (Kozleski and Waitoller, 2010, p. 659).

Similarly to other countries (Darling-Hammond, 2017), teacher education in Portugal can be conceptualised in two distinct phases: Initial Teacher Education which includes teacher induction and is provided by higher education institutions, and ContinuouProfessional Development (CPD). CPD is centrally regulated and in and out-of-school teacher education centres ('Centros de Formação') play a key role in CPD in Portugal. In their analysis of opportunities for teacher learning for diversity in a sample of 137 school clusters in Portugal, Szelei and Alves (2018) conclude that teacher collaboration, peer observation, critical reflection and 'professional development courses' are identified in school policies by Portuguese schools as opportunities for teacher CPD. These approaches seem appropriate modes of teacher education for inclusion, with the potential to support the process of change and the development of an inclusive education system.

\section{Change in schools}

The development of inclusive education requires deep, whole school approaches in which educational change plays a central role (Liasidou, 2015, p. 1). Waves of policy reform are one of the significant forces for change in schools (Hargreaves and Goodson, 2006). Levin and Fullan suggest that a 'positive stance with a focus on motivation', 'capacity building with a focus on results', 'effective use of resources' and good communication and collaboration between different stakeholders is necessary for 
education reforms to result in better outcomes for learners (2008, p. 292). While these seem relevant to changes toward inclusion as indicated in the previous section of this article, the expectation that the change brought by educational reforms must have a small number of ambitious and achievable goals (Levin and Fullan, 2008, p. 292) causes challenges to the change towards inclusive education because its goals can seem 'idealistic' (Armstrong, Armstrong and Spandagou, 2011) and utopic.

Despite educational reforms being one of the forces for change in schools, often 'the initiatives to change schools by introducing new programs, processes and reforms have not resulted in the desired outcomes' (Hall, 2013, p. 264). One of the explanations for this lack of success in implementing change could be linked to educational systems being institutionalised bureaucracies that do not change on demand and which have a propensity to create subunits and subsystems (Skrtic, 1991a, 1991b; Skrtic, Shriner and Harris, 2005). 'Special education' is an example of a subsystem used to avoid deep changes that are required if we want to develop truly inclusive education systems which all learners have access to, and in which all are able to participate and succeed. Another justification for the difficulty to implement change could be related to the exitance of competing agendas, which create added challenges to the stability of education systems. The development of inclusive education requires schools in which the values, pedagogies, curricula and assessment are aligned and take all learners into account. Inclusive education requires negotiating the interests of 'message systems' (Lingard and Mills, 2007) which are often in conflict, for example in regards to the value of educational equity versus the concern for test results (Dyson, Gallannaugh and Millward, 2002; Ainscow, Booth and Dyson, 2006). However, it should be acknowledged that 'any deep (policy) change may involve fears, uncertainty, doubt and also resistance in the agents who are responsible for implementing it' (Freire and César, 2003, p. 344). Given the educational systems resistance to change discussed above a model for managing resistance to change proposed by Kotter and Schlesinger (1979) has been selected as a framework for the policy 'ecology' analysis. This framework will be discussed in the methodology section.

Sustainable change requires a historical perspective on educational change' (Hargreaves and Goodson, 2006, p. 35) to avoid short-term 'transient interests'. Hall (2013, p. 265) presents a cyclical view of educational change but describes the process of repeated change as an 'almost predictable ritual'. According to Hall, this ritual starts with the identification of a problem and desired outcome. This is followed by the selection of a specific programme, process or product, assumed to produce the desired 
outcome. Then teachers and schools go through 'the ceremony of launching the "new way"' and there is an implicit assumption of policymakers and system leaders, in too many cases, is that the "new way" is now in place' (Hall, 2013, p. 265). Given the cyclical nature of education reform waves and that the 'rituals of change' assume that their result is the enactment of policies, the model of change proposed by Lewin (1947) has been selected as a second framework for this study. This model, its affordances and limitations, will be discussed in the methodology section.

In the case of the Portuguese reform, the main 'problem' identified was that the educational system did not realise the right to education for all. The 'desired outcome' was that 'each and every learner would find, in the "regular" education system, responses to their potential, expectation, and needs' (Ministério da Educação, 2018, p. 2918). The Portuguese Ministry of Education has organised initiatives (formal and non-formal teacher education) similar to those described by Hall (2013). These initiatives will be analysed to map the approaches taken to enact change through educational policy reform and the role of teacher CPD for inclusion in the Portuguese context.

\section{Methodology}

This article treats policy as data to be critically analysed (Taylor, 1997) and considers policy as part of a multi-layered 'ecology' (Weaver-Hightower, 2008) particularly relevant when considering policy enactment. Weaver-Hightower proposes that educational policy involves multiple layers (international, national, local, school, classroom), multiple 'stakeholders and influential groups that must be resisted, allied with, answered, or accommodated' as well as multiple 'driving forces (key processes)' and 'structural constraints' (2008, p. 162). The research uses two models of change (Lewin, 1947; Kotter and Schlesinger, 1979) as frameworks to analyse the process of change towards a more inclusive education system. The subsequent sections will present the methodology and design of the study.

\section{Theories of Change in organisations: approaches and strategies}

Theory of change is a systematic and cumulative study of the links between activities, outcomes, and context of the initiative (Fullbright-Anderson, Kubisch and Connell, 1998: 16). Theory of change has been popularised in the 1990 s to capture complex initiatives and scrutinise an initiative based on its outcomes, trying to articulate the underlying assumptions and the reasons for certain outcomes. In 
education, a model of theory of change has been used for example to evaluate the full service extended schools initiative in England (Dyson and Todd, 2010).

Lewin (1947), working on group dynamics, presented a model of change which considered three main steps when targeting successful change: 'Unfreezing', 'Moving' and 'Refreezing'. This model presents a powerful tool when analysing processes of change, particularly when analysing change targeted through national educational policy. This model is useful as it allows the analyst to map the practices presented as 'needing' to be changed and the steps taken to unfreeze, move and freeze existing practices. 'Unfreezing' involves removing 'prejudices', breaking 'open the shell of complacency and self-righteousness' and sometimes requires creating 'an emotional stir up' (Lewin, 1947, p. 35) to break the 'quasi-stationary equilibrium' of existing behaviour. The assumption is that these practices are undesirable and need changing. After practices being 'unfrozen', groups will be able to 'Move' into a new level. Maintaining the 'new' practices can be challenging and 'freezing' practice once the new group norms and routines are established is essential to complete the process of change (Lewin, 1947). The model has been criticised for its third stage of 'freezing' practice, as it can give the impression of creating a new status quo, however, this article suggests that 'freezing' of good practices such as collaboration between various stakeholders and engagement with pupil voice is necessary. Moreover, the approaches to teacher education for inclusion previously discussed in this article do not prescribe the use of particular models or pedagogies, which might need to evolve to follow the development of education systems.

A complementary approach to this analysis is presented by Kotter \& Schlesinger (1979). These authors focus on strategies for managing change and consider the common experience of resistance to change in organisations. While other models of change management have been developed (e.g. Cameron and Green, 2015), the model proposed by Kotter \& Schlesinger (1979) seems appropriate to the analysis of the process of change within educational systems.

Following from the argument presented in the previous section, that education systems are bureaucratic institutions naturally resistant to change (Skrtic, 1991a). The six methods for managing resistance proposed by Kotter \& Schlesinger (1979) are Education, Participation, Facilitation, Negotiation, Manipulation, Coercion. These six strategies overlap significantly with the necessary aspects to successful educational reforms proposed by Levin and Fullan (2008) presented earlier in this paper. Diagram 1 illustrates the suggested overlap between the models proposed by Lewin (1947) and Kotter and Schlesinger (1979): 
$<$ Insert Diagram 1 here $>$

In Kotter and Schlesinger's model (1979) 'Education' refers to the communication of the desired changes and reasons for them, these are linked to awareness-raising about the need for a specific change.

'Participation' consists of the involvement of potential resisters in designing and implementing change; 'Facilitation' is needed when participants require skills training and emotional support to cope with change. 'Negotiation' is the discussion with stakeholders to reach agreements regarding the proposed change. 'Manipulation', which usually involves presenting limited information and organising events in ways that guide stakeholders to accept change - this involves deceiving people. 'Co-optation' is considered one form of manipulation and refers to the involvement of key individuals, for example, someone respected by the group that 'needs to change'. This person is not expected to 'participate' in the change process; rather, the expectation is that they endorse the proposed change. Finally, 'Coercion' can be implicit or explicit and involves 'forcing' people to accept change, for example by threatenng the loss of jobs.

The two models presented in this section were used in the present study as a framework for the critical analysis of the process of policy reform presented. The concept of 'Participation' differs from the one presented by Kotter and Schlesinger (1979) as in this article a broader view of 'participation' is used, referring to the involvement of all participants or stakeholders, not only 'potential resisters'.

\section{Educational policy and policy analysis}

The critical policy analysis uses the models presented in the previous section as a framework for conducting a theoretically informed analysis of the data set. By using the theories of change (Lewin, 1947; Kotter and Schlesinger, 1979) the article attempts to address the criticism made by Taylor who argued that 'little attention has been given to research methodology in the educational policy literature' (Taylor, 1997, p. 24) and that most publications have focused either on commentary and critique of policy, or managerial policy 'evaluation' and that none of these approaches treat the policy as data to be critically analysed. This paper builds on a detailed 'fine grained' analysis (Taylor, 1997, p. 33) of the evolving policies towards inclusive education in Portugal (for an analysis of the development of educational policies related to inclusion in Portugal see Alves, 2019), and considers that policy enactment needs to take into account the broader context through a 'policy ecology framework' (Weaver-Hightower, 
2008). Therefore, the perspective of policy proposed is that it does not only involve what is written (e.g. legislation), but as suggested by Fulcher (1989), that policy includes its written, stated and enacted forms. In other words, written policy is the result of 'political states of play in policy arenas' (Fulcher, 1989), and it is part of a broader ecological system, that reflects international, national, regional, and local dynamics (Weaver-Hightower, 2008).

\section{Inclusion criteria and Data analysis}

This study will analyse evidence from Portugal, where recent national policy changes aimed to create a paradigm shift towards inclusive education in all Portuguese schools. Written policies of the 2017-18 reform in Portugal that contributed to the policy change towards inclusion have been included in the analysis (See table 1). Other items, such as initiatives linked to the implementation of the new policies, have been included as they are considered part of the policy change enactment process and are also relevant to the analysis of the role of teacher continuous professional development for inclusion. The analysis of the data set used the models of change previously presented in this paper and the research questions as an initial thematic framework.

$<$ Insert table 1 here $>$

Items of the policy change 'ecology' included, programmes for initiatives organised or co-organised by the Ministry of Education (mainly formal and non-formal teacher CPD opportunities), chronologically organised:

$<$ Insert table 2 here $>$

\section{Findings}

The findings are organised in seven themes, the first one summarises the changes introduced by the written policies to illustrate the reliance on teacher education to successfully implement the desired change. The subsequent six themes follow the categories proposed by Kotter and Schlesinger (1979). Table 3 presents a mapping of the data onto the frameworks of change.

\section{Interlinked policies: Inclusion, Curriculum, Flexibility, Autonomy and the role of teacher education}

The Decree-Law 54 (Document a, Table 1) refers to 'students who need (additional) support for learning and inclusion measures' and mentions aspects of diversity such as disability (physical, mental, visual, hearing), 'Special Health Needs', language and 'predictors of school failure'. The Decree-Law 54 
(henceforth referred to as DL54) proposes the development of inclusive schools as a means to achieve social inclusion and social cohesion, based on pinciples of 'universal teachability, equity, inclusion, personalisation, flexibility, auto-determination, and parental involvement'. It aims to promote the quality of participation in the mainstream, pushing away 'the need to categorise to intervene'. DL54 requires teachers to identify barriers to learning and to use Universal Design for Learning (CAST, 2018) and a multilevel approach that allows all students to access the curriculum. Mainstream teachers are at the core of this policy change, with various structures and other stakeholders being expected to support the lead role of the mainstream teacher in promoting the quality of the students' participation in mainstream and developing resources (both for teaching and assessment). The structures mentioned are: Learning Support Centres, Inclusion resource centres, Specialised units for students on the autistic spectrum and deafblind students and "user" organisations/ NGOs.

The new curriculum policies, i.e. the Decree-Law 55 (Document b, Table 1) and the 'Essential Learning' (Document f, Table 1) refer to an heterogeneous student population, and reinforce the need not only to remove barriers and stereotypes to achieve inclusive schools, but also to support all students to reach the targets presented in the 'Student Profile' (Document c, Table 1) through a tiered approach proposed in DL54 (a). The DL54 (a) identifies the curriculum and learning as critical key foci of school and proposes that all students must be able to reach the 'Student Profile at the end of Compulsory Schooling' (c). The 'Student Profile at the end of the Compulsory Schooling' (document c, table 1) is aligned with the DL54 (a) in terms of values (e.g. participation, inclusion \& education for all, reflexion), principles (e.g. inclusion, flexibility, sustainability, humanism) and pedagogic principles (e.g. meaningfulness). In sum, the recent policy reform proposed a cluster of interlinked changes to the national educational policies focusing on the curriculum and the way teachers and schools organise additional support for learning and respond to pupils' diversity. In a country that has a centralised system, the DL55 (b) reinforces the importance of school autonomy in enacting the changes proposed by this reform. Given the knowledge required (e.g. about the use of Universal Design for Learning), the extended role of the mainstream teacher (i.e. responsible for all students, supported by other stakeholders), and the greater expectation of increased teacher reflexivity and school autonomy, teacher education plays a central role in the successful implementation of this reform. 
The way the DL54 (Document a, table 1) is written is a good example of how written policy can create a sense of urgency for change. Its direct reference to the UN Sustainable Development Goals, the UN Convention on the Rights of Persons with Disabilities (United Nations, 2006), the UNESCO Policy Guidelines on Inclusion in Education (UNESCO, 2009), and the Lisbon Educational Equity Statement, issued by the delegates at the 8th Inclusive and Supportive Educational Congress, which refers to the United Nations' Education for All agenda to the Incheon Declaration (UNESCO, 2015), makes this education reform wave part of broader attempt to create more just societies. In the case of this policy reform, the changes in written policy were accompanied by a series of events to raise teacher's awareness of the need for change. Initiatives such as public discussions (Initiatives i and p, Table 2), conferences, presentations and seminars (Initiatives j, 1, o, Table 2), and teacher education (Initiatives h, k, m, n, Table 2) were ways of problematising or 'unfreezing' current practices by creating a sense that the current practices were 'wrong', and needed changing. All of these were free events, and most were open to all teachers and to the wider community.

The role of school inspections (Initiatives g, Table 2) to disseminate good practices were also used as a way of raising awareness of the need and possibilities for change.

$<$ Insert Table 3 here $>$

\section{Participation}

Participation and teacher involvement in the process of educational reform analysed in this paper were mainly promoted through public discussions of the legal frameworks, both before its publication (Initiative i, Table 2) and after (Initiative p, Table 2) with a view to collect the public's views so they could be used in the development or redesign of the DL 54/2018. Through these events, some common ground between policy-makers and stakeholders was created, which could facilitate the process of change.

\section{Facilitation}

As portrayed by the included initiatives (Table 2), the process of 'Facilitation' was targeted at the level of CPD and was not visible at the level of ITE. The Ministry of Education organised online training (Initiatives h, n, Table 2) and training 'in person' (Initiatives m, k, Table 2). Given the perspective of inclusion as a (challenging) process that will always create challenges and dilemmatic situations, facilitation through teacher education, namely through collaborative practices, is important not only to 
'move' to a new practice but also to validate and 'freeze' the desired practice. The role of school inspections (Initiative g, Table 2) to foster collaboration and the dissemination of good practices can be a way to support the 'move' to the new and desirable practices.

\section{Negotiation and 'experimental' change}

Negotiation takes two main forms, on one hand through 'participation', as previously discussed, policymakers can collect and act upon issues raised by teachers and schools and incorporate them in the development of the DL54 (Document a, Table 1), and in its planned evaluation and changes (Initiatives i, p, Table 2).

On the other hand, negotiation was done to a greater extent with schools involved in experimental projects. Following a common trend in Portuguese education, two experimental projects were used in the process of reform: "Project Autonomy and Curriculum Flexibility" (Document d, Table 1) and "Pilot Project of Pedagogical Innovation” (Document e, Table 1). In the first project 226 schools voluntarily signed up to have autonomy and flexibility to manage up to $25 \%$ of their curriculum (Document d, Table 1). After one experimental year, the initiative was extended to all Portuguese schools through the DL 55 (Document b, Table 1). The second project (Document e, Table 1) involved six schools, invited by the Ministry of Education, to 'create and implement alternative solutions that create quality education for all learners and grade retention close to zero' (DGE, online; See Kovacs and Tinoca, 2017).

The increased autonomy of these schools and proximity to policy-makers put them in a privileged position of being able to negotiate needs, even though the scope for negotiation was limited by the policy boundaries (e.g. the six schools in the pilot project were set the challenge of improving through changes to their organisation, without the provision of extra funding or resources by the Ministry of Education).

\section{Co-optation}

The awareness-raising events (Initiatives $\mathrm{j}, 1, \mathrm{o}$, Table 2 ) were in most cases linked to some form of cooptation as key international and national entities took a pivotal role and endorsed the need for change (e.g. Gordon Porter, Andreas Schleicher; Ariana Cosme, David Rodrigues, school leaders, teachers, and students from 'successful' schools). Additionally, the schools that participated in the experimental projects (Document d, e, Table 1) endorsed the need for change. 


\section{Coercion}

School inspections are expected to 'support, monitor and evaluate' the implementation of DL54 (Document a, Table 1) and DL55 (Document b, Table 1). While school inspections already took place before the recent reform, changes to the process mean that they now also aim to monitor the level of inclusivity of schools, which had not been the case in previous years (Document g, Table 2).

\section{Discussion and conclusions}

What changes took place in educational policy in Portugal related to inclusion, during the 2017-18? 2017-18 brought a number of changes to educational policy in Portugal related to inclusion. Recent changes in educational policy in Portugal pushed inclusion as a value and a 'policy priority' (Armstrong, Armstrong and Spandagou, 2011, p. 38). The new policies redefined the target group of inclusive education, moving away from the notion of SEN, and reorganising the schools' responses into a noncategorical tiered system in which mainstream and special educations teachers' roles were expected to change too. Mainstream teachers are now expected to be responsible for all students, and to use Universal

Design for Learning, while special education teachers are considered specialist resources for the schools, mainstream teachers, and students. . However, the new written policies did not apply solely to 'special needs and inclusion' as has been the tendency in the past (Alves, 2019), conversely, they involved wider changes in the national curriculum, principles of assessment, and levels of school autonomy.

\section{What processes were used to implement these changes?}

The process of change involved various actions to 'unfreeze' existing beliefs and practices (such as the existence of 'special teachers' for 'special children' and the preference for one-to-one out of class support delivered by special teachers) and to move practices to a 'new' level. Awareness-raising took a central role in 'unfreezing' existing practices and promoting the feeling on a 'need' for change. The mission of raising awareness involved to some extent 'co-optation', i.e. the involvement of key figures (from 'successful' schools, academia and international organisations) to help 'convince' those resisting change. This wave of policy reform also involved a series of moments in which all teachers were invited to participate and voice their opinions and concerns about the changes to the legislation. These instances of awareness-raising and participation mentioned above created opportunities for communication between teachers and policy-makers, which was complemented by the involvement of schools which were 
considered by the Ministry of Education to be 'ahead' in the process of change. Nevertheless, in many cases, and given the resistance of educational systems to change (Skrtic, 1991a), other processes are needed to prompt the 'move' into new practices. For teachers to 'unfreeze' practices that are well established the process of change needs to be built upon teacher education processes that facilitate and support change towards inclusion. moreover, even if the current practices were 'unfrozen', 'moving' to adopting new practices in a sustainable way, requires 'facilitation' in which teacher continuous professional development plays a key role. Even though 'teacher education is only one component of what is needed to enable high-quality teaching, it is essential to the success of all the other reforms urged on schools' (Darling-Hammond, 2006, p. 312). In other words, the support provided to teachers to encourage the 'move' to new ways of responding to pupil diversity (Facilitation), is essential to create a 'move' to new practices, and teacher education for inclusion plays a key role in facilitating change. While for some teachers 'awareness-raising' and the changes in written policy might push for change, 'facilitation' is essential to support teachers in the process of becoming more inclusive.

\section{What role did teacher education play in this process?}

This article argues that teacher education for inclusion, as described by Rouse (2008), plays a key role in the process of deep change towards inclusion in schools. In the case of the policy reform reviewed, some opportunities for CPD were created by the Ministry of Education to increase teachers' knowledge of the policy context, of the principles of Inclusion and Universal Design for Learning, and specific knowledge to respond to certain groups of students. These were organised as a mixture of formal and non-formal learning situations. However, it is unclear whether these TE opportunities remain at an 'intellectually superficial' level (Darling-Hammond, 2017), without creating 'interruptions' that help 'making the familiar unfamiliar' (Ainscow, 2005, p. 116) and 'move' schools to a more inclusive paradigm. Portuguese policy-makers did not assume that the 'new way' was now in place (Hall, 2013, p. 265) and built in the final 'strategy' to manage change proposed by Kotter \& Schlesinger (1979), 'coercion' under the guise of school inspections to monitor the change and thus drive the 'freezing' of the desired practice. Given the complexity of inclusion and the expected increased levels of school autonomy, the inspections now have to increasingly deal with what has been presented by Dyson and Todd as 'high levels of complexity, indeterminacy, and variability' (2010, p. 131). This complexity may require a change to the 'model of the evaluator as a detached observer passing authoritative judgements on success and failure' 
(Dyson and Todd, 2010, p. 131). The teams tasked to support, monitor and evaluate the implementation of change, will probably also play to some extent a role of teacher educators. Even if this will depend greatly on the approach of each inspection team.

\section{Conclusions: What impact do the new educational policies have on Teacher Education for Inclusion?}

The new educational policies require changes to Teacher Education, which must prepare all teachers for inclusion. This reform expects mainstream teachers to be responsible for all learners and this has an impact on the teachers' needs both in initial teacher education and continuing professional development. Given the increasing awareness about pupil diversity, it is not realistic to expect that teachers leave ITE knowing how to respond to all learners. Furthermore, if we want to ensure the presence, participation, and success of all students, teacher education needs to use approaches to facilitate the process of change, by turning knowledge into action (Rouse, 2008) and allowing teachers to experiment in a supported way, reflect and collaborate with others (Borko, 2004; Meirink et al., 2009; Bakkenes, Vermunt and Wubbels, 2010; Meijer, 2013).

However, if we continue to evaluate the success of the implementation of these changes through its outcomes as it has traditionally been done (e.g. number of students reaching certain grades), the message conveyed to schools and teachers poses a conflict between competing agendas: inclusion and standardised testing (Dyson, Gallannaugh and Millward, 2002) which cannot be solved through teacher education. The change to inclusive education paradigms in any context requires critical reflection on the meaning of 'success'. If success is conceptualised in non-inclusive ways, the schools' priorities might not lie in creating inclusive schools.

This paper examined the processes of change introduced through educational policy reform towards inclusive education and considered the pivotal role of teacher education in this process. The specific example of enactment of an educational policy reform in Portugal has been analysed using theories of change (Lewin, 1947; Kotter and Schlesinger, 1979). In future research, it would be productive to apply the framework proposed in this article to other countries to interrogate policy-driven processes of change in educational systems.

While policies and policy change play a role in creating more inclusive education systems, inclusive policies do not always equate to inclusive practices in the schools and classrooms. Teacher education can play a key role in this process as a way to 'unfreeze' and 'move' practices, as well as to 'freeze' reflexive, collaborative practices, especially in a wave of policy reform that expects schools and teachers to have 
increased autonomy levels to respond to their specific learning and teaching contexts.

\section{References}

Ainscow, M. (2005) 'Developing inclusive education systems: what are the levers for change?', Journal of Educational Change, 6, pp. 109-124.

Ainscow, M., Booth, T. and Dyson, A. (2006) 'Inclusion and the standards agenda: Negotiating policy pressures in England', International Journal of Inclusive Education, 10(4-5), pp. 295-308.

Ainscow, M., Slee, R. and Best, M. (2019) 'Editorial: the Salamanca Statement: 25 years on', International Journal of Inclusive Education. Taylor \& Francis, 23(7-8), pp. 671-676.

Alves, I. (2019) 'International inspiration and national aspirations: inclusive education in Portugal', International Journal of Inclusive Education. Taylor \& Francis, 23(7-8), pp. 862-875.

Armstrong, D., Armstrong, A. C. and Spandagou, I. (2011) 'Inclusion: by choice or by chance?', International Journal of Inclusive Education, 15(1), pp. 29-39.

Arnesen, A.-L. et al. (2008) Policies and practices for teaching socio-cultural diversity, Teacher Education. Strasbourg: Council of Europe Publishing.

Bakkenes, I., Vermunt, J. D. and Wubbels, T. (2010) 'Teacher learning in the context of educational innovation: Learning activities and learning outcomes of experienced teachers', Learning and Instruction. Elsevier Ltd, 20(6), pp. 533-548.

Booth, T. and Ainscow, M. (2002) Index for inclusion: developing learning and participation in schools. Bristol: Centre for Studies on Inclusive Education.

Borko, H. (2004) 'Professional Development and Teacher Learning':, October, (November 2004), pp. $3-15$.

Burns, T. and Shadoian-Gersing, V. (2010) 'The importance of effective teacher education for diversity', in Educating Teachers for Diversity: Meeting the Challenge. OECD Publishing, pp. 19-40.

Cameron, E. and Green, M. (2015) Making Sense of Change Management, Kogan Page Limited. CAST (2018) 'Universal design for learning guidelines version 2.2'. Wakefield, MA, p. 2018. Costa, A. M. B. da and Rodrigues, D. A. (1999) 'Country Briefing Special education in Portugal', European Journal of Special Needs Education, 14(1), pp. 70-89.

Darling-Hammond, L. (2006) ‘Constructing 21st-Century Teacher Education', Journal of Teacher Education, 57(3). 
Darling-Hammond, L. (2017) 'Teacher education around the world: What can we learn from international practice?', European Journal of Teacher Education. Routledge, 40(3), pp. 291-309.

Dyson, A. (1999) 'Inclusion and inclusions: theories and discourses in inclusive education', in Daniels, H. and Garner, P. (eds) World yearbook of education 1999: Inclusive Education. London: Kogan Page, pp. 36-53.

Dyson, A., Gallannaugh, F. and Millward, A. (2002) 'Making space in the standards agenda: developing inclusive practices in schools', 0044(September), pp. 12-14.

Dyson, A. and Todd, L. (2010) 'Dealing with complexity: Theory of change evaluation and the full service extended schools initiative', International Journal of Research and Method in Education, 33(2), pp. 119-134.

European Agency for Special Needs (2012) Teacher Education for Inclusion: Profile of Inclusive Teachers. Odense: European Agency for Development in Special Needs Education.

European Agency for Special Needs and Inclusive Education (2017) ‘Agency Position on Inclusive Education', pp. 1-2.

Flores, M. A. and Ferreira, F. I. (2016) 'Education and child poverty in times of austerity in Portugal: implications for teachers and teacher education', Journal of Education for Teaching. Routledge, 42(4), pp. 404-416.

Florian, L. (2012) 'Preparing Teachers to Work in Inclusive Classrooms: Key Lessons for the Professional Development of Teacher Educators from Scotland's Inclusive Practice Project', Journal of Teacher Education, 63(4), pp. 275-285.

Florian, L. (2019) 'On the necessary co-existence of special and inclusive education', International Journal of Inclusive Education. Taylor \& Francis, 23(7-8), pp. 691-704.

Forlin, C. (2001) 'Inclusion: Identifying potential stressors for regular class teachers', Educational Research, 43(3), pp. 235-245.

Forlin, C., Douglas, G. and Hattie, J. (1996) 'Inclusive Practices: How accepting are teachers?', International Journal of Disability, Development and Education, 43(2), pp. 119-133.

Freire, S. and César, M. (2003) 'Inclusive Ideals/ inclusive practices: how far is a dream from reality? Five comparative case studies', European Journal of Special Needs Education, 18(3), pp. 341-354. Fulcher, G. (1989) Disabling policies?: a comparative approach to education policy \& disability, Disability, handicap \& life chances series. London: Falmer Press. 
Hall, G. E. (2013) 'Evaluating change processes: Assessing extent of implementation (constructs, methods and implications)', Journal of Educational Administration, 51(3), pp. 264-289.

Hargreaves, A. and Goodson, I. (2006) 'Educational change over time? The sustainability and nonsustainability of three decades of secondary school change and continuity', Educational Administration Quarterly, 42(1), pp. 3-41.

Hart, S. et al. (2004) Learning without limits. Maidenhead: Open University Press.

Kotter, J. P. and Schlesinger, L. A. (1979) 'Choosing strategies for change.', Harvard Business Review, 57(2), pp. 106-114.

Kovacs, H. and Tinoca, L. (2017) 'Unfreeze the pedagogies: introduction of a new innovative measure in Portugal', Revista Tempos e Espaços em Educação, 10, pp. 73-86.

Kozleski, E. B. and Waitoller, F. R. (2010) 'Teacher learning for inclusive education: understanding teaching as a cultural and political practice', International Journal of Inclusive Education, 14(7), pp. $655-666$.

Levin, B. and Fullan, M. (2008) 'Learning about system renewal', Educational Management Administration and Leadership, 36(2), pp. 289-303.

Lewin, K. (1947) Frontiers in Group Dynamics: Concept, Method and Reality in Social Science; Social Equilibria and Social Change, Human Relations.

Liasidou, A. (2015) Inclusive Education and the Issue of Change.

Lingard, B. and Mills, M. (2007) 'Pedagogies making a difference: Issues of social justice and inclusion', International Journal of Inclusive Education, 11(3), pp. 233-244.

Lloyd, C. (2010) 'Excellence for all children false promises! The failure of current policy for inclusive education and implications for schooling in the 21st century', International Journal of Inclusive Education, 4(2), pp. 133-151.

Meijer, C. J. (2013) 'European agency: key messages and outlook', in Inclusive Education in Europe: Putting theory into practice. European Agency for Special Needs and Inclusive Education, pp. 8-11. Meirink, J. A. et al. (2009) 'Understanding teacher learning in secondary education: The relations of teacher activities to changed beliefs about teaching and learning', Teaching and Teacher Education. Elsevier Ltd, 25(1), pp. 89-100.

Messiou, K. et al. (2016) 'Learning from differences: a strategy for teacher development in respect to student diversity', School Effectiveness and School Improvement. Routledge, 27(1), pp. 45-61. 
Ministério da Educação (2018) Decreto-Lei 54/2018.

Mittler, P. (2000) Working towards inclusive education: social contexts. London: David Fulton.

Moltó, M. C. C. et al. (2010) 'Attitudes to diversity: a cross-cultural study of education students in Spain, England and the United States', European Journal of Teacher Education, 33(3), pp. 245-264. Pijl, S. J., Meijer, C. J. W. and Hegarty, S. (1997) 'Inclusive education: a global agenda' London: Routledge.

Rodrigues, D. and Nogueira, J. (2011) 'Special and inclusive education in Portugal: facts and options', Revista Brasileira Educacao Especial, 17(1), pp. 3-20.

Rouse, M. (2008) 'Developing Inclusive Practice: A Role for Teachers and Teacher Education?', Education in the North, 16, pp. 6-13.

Skrtic, T. M. (1991a) 'Students with Special Educational Needs: Artifacts of the traditional curriculum', in Ainscow, M. (ed.) Effective schools for all. London: David Fulton Publishers, pp. 20-42.

Skrtic, T. M. (1991b) 'The Special Education Paradox: Equity as the Way to Excellence', Harvard Educational Review, 61(2), pp. 148-206.

Skrtic, T. M., Shriner, J. G. and Harris, K. R. (2005) Special education policy and practice: accountability, instruction, and social challenges. Denver: Love Publishing.

Szelei, N. and Alves, I. (2018) 'The Missing Link: Teacher Learning for Diversity in an Area-based Initiative in Portugal', Center for Educational Policy Studies Journal, 8(3), p. 79.

Taylor, S. (1997) 'Critical Policy Analysis: exploring contexts, texts and consequences', Discourse: Studies in the Cultural Politics of Education, 18(1), pp. 23-35.

Thomas, G. and Vaughan, M. (2004) Inclusive Education: Readings and Reflections, Inclusive Education. Maidenhead: Open University Press.

UNESCO (2009) 'Policy guidelines on inclusion in education', Unesco, pp. 1-36.

UNESCO (2015) 'Incheon Declaration and Framework for Action', pp. 1-84.

UNESCO (2017) A guide for ensuring inclusion and equity in education. Paris: UNESCO.

United Nations (2006) Convention on the Rights of Persons with Disabilities.

United Nations (2015) 'Transforming our world: the 2030 Agenda for Sustainable development'. Weaver-Hightower, M. B. (2008) 'An Ecology Metaphor for Educational Policy Analysis: A Call to Complexity', (APRIL), pp. 153-167. 